\title{
Candomblé e Sus Num Diálogo para a Construção de um Projeto de Saúde para o Povo-De-Santo À Luz da Biossegurança.
}

\author{
Silva, Marcio Azevedo da; Geisler, Adriana \\ Ipec - Fiocruz - marcio.azevedo@ipec.fiocruz.br
}

Introdução: o candomblé, mais que religião, é um espaço de resistência e afirmação da identidade e cultura afrodescendente. Contudo, este carrega um forte estigma, histórica e socialmente construído, observado pela discriminação naturalizada nas práticas de intolerância religiosa e racismo institucional, o que impacta negativamente a saúde do negro e consequentemente do povode-santo. a interface fé-religião-saúde é uma linha tênue e espaço permanente de conflitos e negociações entre profissionais e praticantes das diversas religiões, o que reflete a precarização do ensino em saúde, cada vez mais tecnicista e distante da subjetividade humana. Culto brasileiro de matriz africana, iniciático e essencialmente sacrificial, o candomblé envolve com frequência a manipulação de lâminas, navalhas e outros perfurocortantes no cotidiano de suas práticas rituais, figurando como objeto de interesse da biossegurança. Entretanto, o confronto entre a literatura biomédica e das religiões afrobrasileiras revela uma lacuna de conhecimento tangente a essa questão. Objetivo: investigar os saberes e práticas dos candomblecistas frente ao risco de transmissão de doenças infecciosas relacionadas à sua prática religiosa, refletindo sobre o papel e a atuação do SUS na garantia do direito à saúde desse grupo. Métodos: estudo de abordagem qualitativa, a partir dos pressupostos da comunidade ampliada de pesquisa (CAP), definida como uma ferramenta metodológica de cooperação entre saberes científicos e da experiência, operando uma dialética entre "teoria e prática", que possibilita a produção de conhecimento e ações de mudança assumidas pelos indivíduos que vivenciam os problemas no seu cotidiano. Resultados esperados: ampliar a produção de conhecimento nesta área específica, visando compensar a lacuna na formação dos profissionais de saúde por meio da educação inicial e permanente. e subsidiar o processo que indique novas modalidades de atenção à saúde do praticante de religiões afrobrasileiras, ampliando seu acesso à prevenção de doenças infecciosas. Considerações finais: Este estudo propõe que candomblecistas definam ações sobre a sua própria saúde, assumindo que os mesmos estão habilitados para elaborar seu projeto de saúde integral, incluindo questões relativas à sua prática religiosa. Transitar nesse universo nos impõe desafios éticos e epistemológicos. Éticos, porque a nós não interessa a classificação ou censura destas práticas religiosas, já tão aviltadas pelo processo histórico-social que, ainda hoje, as demoniza e desqualifica. e epistemológicos, uma vez que envolve questões tão subjetivas e complexas quanto o próprio ser humano e sua relação com o(s) mundo(s). por fim, a CAP como estratégia metodológica pode colaborar para inventar e propor novas formas para serem experimentadas na produção de conhecimento, outros modos de ser trabalhador de saúde e afirmar a importância de se produzir práticas e saberes com os humanos e não apenas sobre eles.

Silva, Marcio Azevedo da; Geisler, Adriana. Candomblé e Sus Num Diálogo para a Construção de um Projeto de Saúde para o Povo-De-Santo À Luz da Biossegurança.. In: Anais do Congresso Internacional de Humanidades \&

Humanização em Saúde [= Blucher Medical Proceedings, num.2, vol.1]. São Paulo: Editora Blucher, 2014. ISSN 23577282

DOI 10.5151/medpro-cihhs-10596 